\title{
Odontogenic myxoma: Ultrastructural and histochemical studies
}

\author{
J. D. HARRISON
}

From the Department of Oral Pathology, King's College Hospital Dental School, London

SYNOPSIS An odontogenic myxoma of a maxilla has been examined. Histochemistry of the mucosubstance indicated that hyaluronic acid and chondroitin sulphate were present. On ultrastructural examination many of the cells in the myxomatous tissue were seen with prominent rough endoplasmic reticulum, suggesting a secretory function, and possibly the myxomatous ground substance was produced by these cells. Cells containing collagen fibrils were found. Epithelial islands with intercellular spaces producing an arrangement similar to the stellate reticulum of the enamel organ were found, and possibly had developed from odontogenic epithelial rests. These islands were surrounded by a clear zone, outside which were cells with an increased prominence of adenosine-triphosphatase, nucleoside-diphosphatase, thiamine-pyrophosphatase, and often arylamidase reaction products. This probably represents a reaction of the mesodermal tissue to the epithelial islands. Possibly the epithelium exerts an inductive effect on the mesodermal tissue, and the myxomatous appearance may be the result of an aberrant development of mesodermal cells into 'myxoblasts' which secrete the myxomatous ground substance.

A considerable number of odontogenic myxomas have been studied by means of routine histological techniques (Zimmerman and Dahlin, 1958; Barros, Dominguez, and Cabrini, 1969; Gorlin, 1970; Pindborg, 1970; Whitman, Stewart, Stoopack, and Jerrold, 1971 ; Cawson, 1972). Two more specialized studies have been a thorough study of the chemistry and histochemistry of the mucosubstance by Hodson and Prout (1968) and a histochemical study by Sedano and Gorlin (1965), both these studies being primarily of single cases.

In the present investigation a maxillary tumour which was found on preliminary biopsy to be an odontogenic myxoma has been studied after removal by means of routine histological techniques, enzyme and mucosubstance histochemistry, and electron microscopy.

\section{Materials and Methods}

The tumour occupied the right maxilla of an otherwise fit woman of 21 years who had noticed swelling of the right face for at least three years. The case history will be reported elsewhere (Harrison and Eggleston, 1973). Upon removal of the tumour a Received for publication 31 May 1973. pyramid of tissue extending to the centre of the tumour was removed. The cut surface was white and the tissue was of a rubbery consistency. The apical part of this pyramid was preserved in several ways.

\section{MUCOSUBSTANCE HISTOCHEMISTRY AND} ROUTINE HISTOLOGY

A piece of tissue was fixed overnight at $0-4^{\circ}$ in $10 \%$ formalin with $0.9 \%$ saline and $2 \%$ calcium acetate and was subsequently wax-embedded. Sections were cut at $5 \mu$.

Mucosubstances containing vic-glycols were demonstrated by the periodic-acid Schiff technique (Stoward, 1967, but with Schiff's reagent from G. T. Gurr). Glycogen was detected by the disappearance of its staining with the periodic-acid Schiff technique after incubating sections for one hour at $37^{\circ}$ in an aqueous solution of $0.1 \%$ malt diastase (Sigma).

Acidic mucosubstances were demonstrated by staining with $0.05 \%$ Alcian Blue 8GX at pH 2.5 (Mowry, 1956) or by the Alcian Blue critical electrolyte concentration technique at $\mathrm{pH} 5.8$ with $0.05,0.2,0.4,0.6$, or $0.9 \mathrm{M} \mathrm{MgCl}_{2}$ (Scott and Dorling, 1965).

Some sections were incubated with $0.1 \%$ staphylococcal hyaluronidase (Organon Laboratories Ltd) 
to remove hyaluronic acid (Linker, Meyer, and Hoffman, 1956; Linker, Hoffman, Meyer, Sampson, and Korn, 1960; Spicer, Horn, and Leppi, 1967) or with $0.1 \%$ bovine testicular hyaluronidase (type I, Sigma) to remove chondroitin sulphates $A$ and $C$ and hyaluronic acid (Linker et al, 1960; Spicer et al, 1967). The enzymes were dissolved in normal saline and the incubations were for three hours at $37^{\circ}$. Control sections were incubated in normal saline. These sections were then stained either by Alcian Blue at $\mathrm{pH} 2.5$ or at $\mathrm{pH} 5.8$ with $0.05 \mathrm{M} \mathrm{MgCl}_{2}$. The removal of stainable material by the enzymes was observed by comparing sections stained after enzyme treatments with those stained after treatment with saline alone.

For histological examination, sections were stained with haematoxylin and eosin or the van Gieson technique for collagen (Fullmer, 1965).

The hyaluronidase digestions and staining with Alcian Blue at $\mathrm{pH} 2.5$ were also applied to the following tissues: a myxoma removed from the gingiva associated with the lower first and second molars of a woman of 35 years; a myxoma associated with the follicle of an unerupted upper canine in a girl of 10 years; an odontogenic fibroma situated on an edentulous lower alveolus in a woman of 68 years; two umbilical cords; and buccal salivary glands.

\section{ENZYME HISTOCHEMISTRY}

Pieces of tissue of about $3 \mathrm{~mm}$ diameter were fixed for 16 hours at $0-4^{\circ}$ in $4 \%$ formaldehyde (freshly prepared from paraformaldehyde) in $0.08 \mathrm{M}$ cacodylate buffer $\mathrm{pH} 7.2$ with $7.5 \%$ sucrose and $0.05 \%$ calcium chloride, and were then rinsed in $0.05 \mathrm{M}$ cacodylate buffer $\mathrm{pH} 7 \cdot 2$ with $7 \cdot 5 \%$ sucrose for about 60 hours at $0-4^{\circ}$ before quenching in hexane cooled by solid carbon dioxide. This tissue will be referred to as 'prefixed' tissue. Other pieces of tissue were quenched upon removal without prior fixation. The quenched pieces were stored at $-70^{\circ}$.

Cryostat sections of about 10 to $12 \mu$ were mounted on slides or coverslips. The following enzyme histochemical techniques were applied to sections of prefixed tissue and to sections of unfixed tissue which had been fixed in the formol-sucrose fixative for five minutes at $0-4^{\circ}$ (postfixed tissue): adenosine triphosphatase using a modification of the technique of Wachstein and Meisel (1957) with 1.8 $\mathrm{mM}$ lead nitrate and $20 \mathrm{mM}$ magnesium sulphate; nucleoside diphosphatase using inosine diphosphate (Smith and Farquhar, 1970); thiamine pyrophosphatase using similar concentrations to those used by Smith and Farquhar (1970); alkaline phosphatase (Stutte), 1967; acid phosphatase (azo-dye and metalprecipitation techniques of Barka and Anderson, 1962); beta-glucuronidase (Hayashi, Nakajima, and Fishman, 1964); non-specific esterase (Davis, 1959) with either $0.03 \mathrm{mM}$ eserine to inhibit cholinesterase activity (Koelle, 1955) or $0.01 \mathrm{mM}$ E600 to inhibit organophosphate-sensitive esterases (Bulmer and Fisher, 1970); and peroxidase (Graham and Karnovsky, 1966). Arylamidase activity (Patterson, Hsiao, and Keppel, 1963) was demonstrated in prefixed and unfixed sections by a technique originally considered specific for leucine-aminopeptidase (Nachlas, Monis, Rosenblatt, and Seligman, 1960). Techniques for the following enzymes were applied to unfixed sections: cytochrome oxidase (Burstone, 1961); succinic dehydrogenase (Nachlas, Tsou, de Souza, Cheng, and Seligman, 1957); and NADH- and NADPH-diaphorases using NADH and NADPH (as in the method of Scarpelli, Hess, and Pearse, 1958) and nitro-BT (as suggested by Nachlas et al, 1957).

\section{ELECTRON MICROSCOPY}

Pieces of tissue of about $1 \mathrm{~mm}$ diameter were immersed for two hours at room temperature in a fixative consisting of $4 \%$ acrolein, $5 \%$ glutaraldehyde, and $4 \%$ formaldehyde (freshly prepared from paraformaldehyde) in $0.08 \mathrm{M}$ cacodylate buffer pH 7.2 with $0.05 \%$ calcium chloride (based on Karnovsky, 1965, and Rodríguez, 1969). The pieces were rinsed, osmicated, dehydrated, and embedded in araldite. Ultrathin sections were examined in an electron microscope after staining with uranyl acetate and lead citrate or with lead citrate alone. Thicker sections were stained with Toluidine Blue and examined light microscopically.

\section{Results}

\section{HISTOLOGY}

The bulk of the tumour was composed of a faintly basophilic myxomatous ground substance in which cells of various size and shape were dispersed (figs $1,2,3$, and 4). A variable number of fibres was found coursing throughout the ground substance (figs 1 , 2,3 , and 4). 'Cavities' with a poorly defined lining of fibres were found (fig 2). Thin-walled vessels, occasionally containing red blood corpuscles, were frequently associated with 'cavities', either within or adjacent to them (fig 2).

Epithelial islands were found at intervals throughout the tissue (figs 1, 2, 3, and 4). In some islands no intercellular spaces were seen (fig 1), whilst in most there were conspicuous intercellular spaces (figs 2,3 , and 4). The islands with intercellular separation were surrounded by a clear zone relatively poor in fibres and cells (figs 2, 3, and 4). Such a zone was not usually seen around islands without intercellular separation (fig 1). 


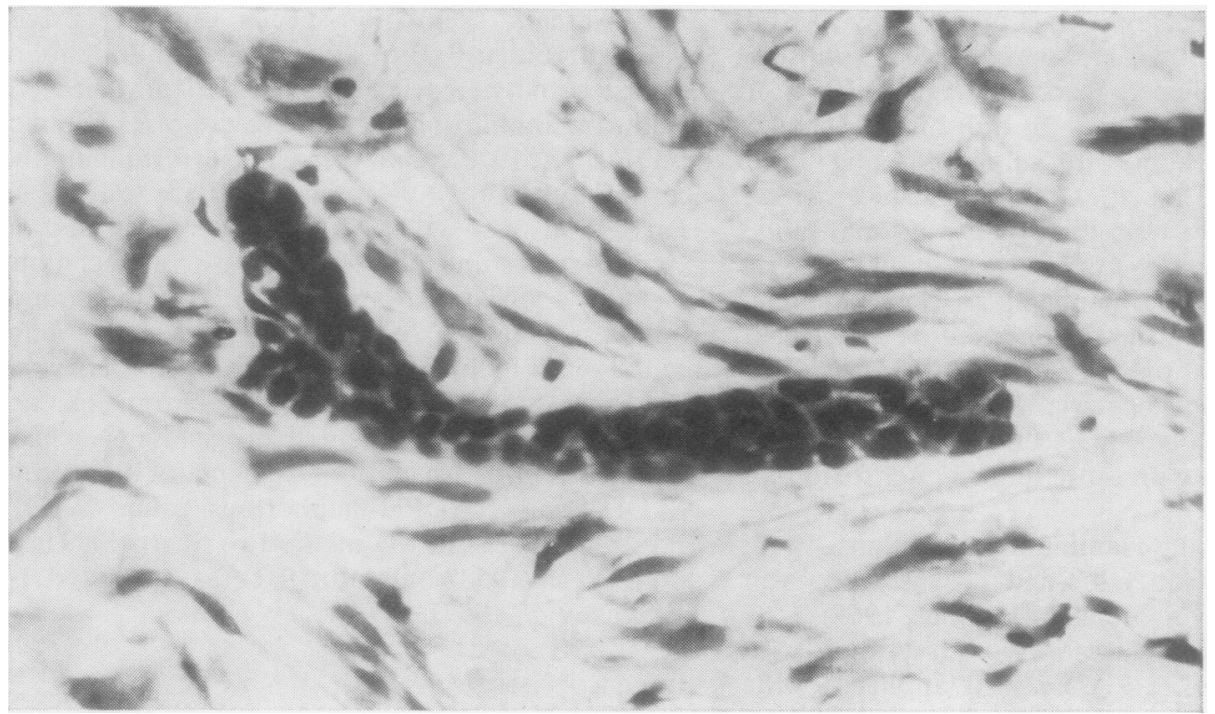

Fig 1

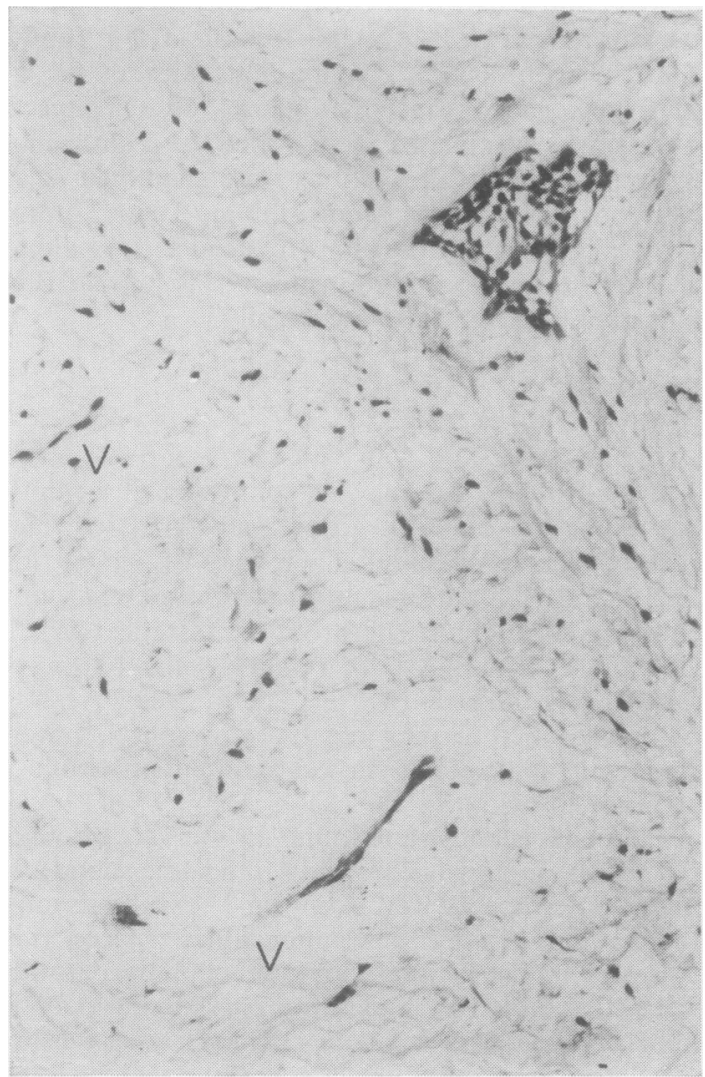

Fig 1 Section shows myxomatous tissue and an epithelial island with negligible intercellular separation. Haematoxylin and eosin, $\times 410$.

Fig 2 Section shows myxomatous tissue and several thin-walled vessels (V), one being within a cavity. An epithelial island is seen with considerable intercellular separation, and it is surrounded by a clear zone relatively poor in fibres and cells. Haematoxylin and eosin, $\times 180$.

Fig 2 


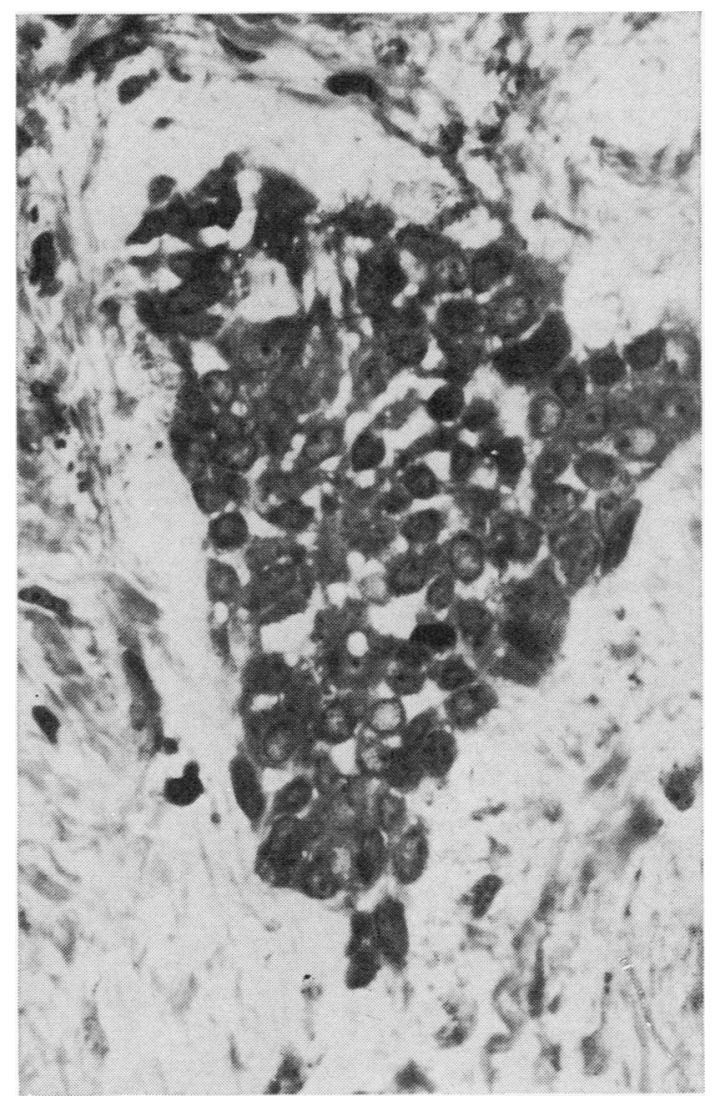

Fig 3 Light-microscopical araldite section adjacent to section viewed electron-microscopically in figure 16. There is some intercellular separation in the epithelial island, which is surrounded by a clear zone. Bundles of fibres are elsewhere conspicuous in the myxomatous tissue. Toluidine Blue, $\times 360$.

\section{MUCOSUBSTANCE HISTOCHEMISTRY}

With the periodic-acid Schiff technique there was faint diastase-resistant staining of the sections. Glycogen was demonstrated in many cells in the myxomatous tissue and in many cells in the epithelial islands.

With the Alcian Blue critical electrolyte concentration technique the sections were stained moderately with $0.05 \mathrm{M} \mathrm{MgCl}$, weakly with $0.2 \mathrm{M}$, very weakly with $0.4 \mathrm{M}$, faintly with $0.6 \mathrm{M}$, and were not stained with 0.9 M. Mast cells were not seen.

Sections were moderately stained by Alcian Blue at pH 2.5 (fig 5). When sections were incubated in saline alone or with the hyaluronidases before staining with Alcian Blue at pH 2.5, it was found that there was a slight decrease in staining after saline alone (fig 6), a greater decrease after staphylococcal

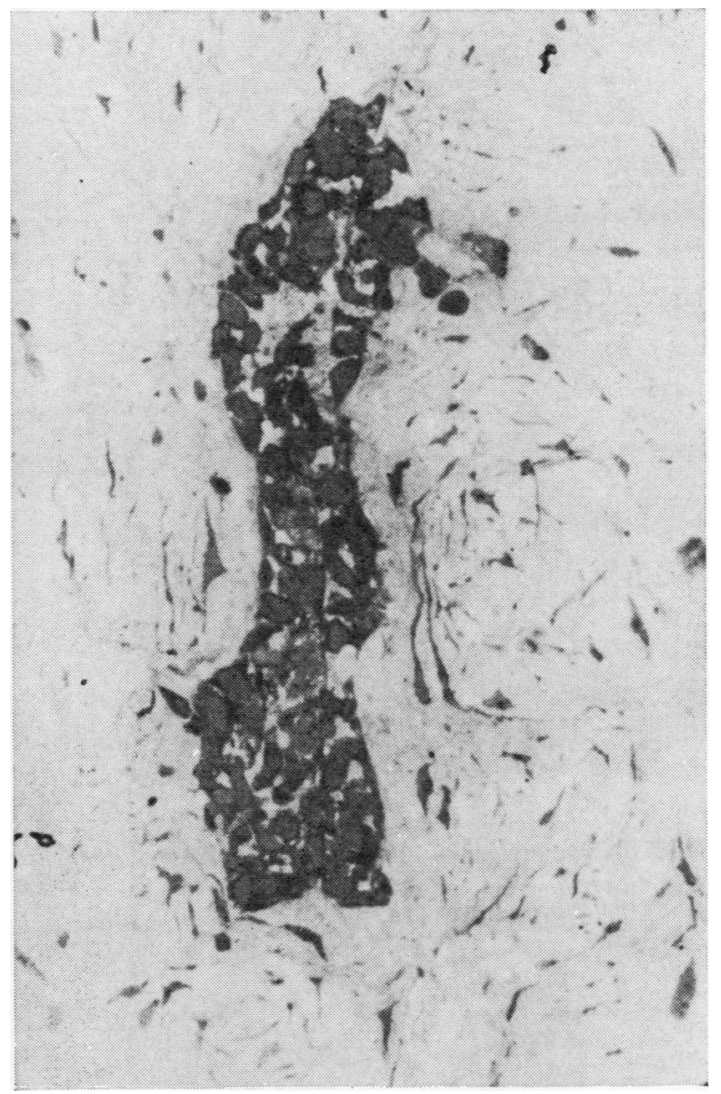

Fig 4 Light-microscopical araldite section adjacent to section viewed electron-microscopically in figure 17.

There is considerable intercellular separation in parts of the epithelial island, which is surrounded by a clear zone. Few fibres are present in the myxomatous tissue. Toluidine Blue, $\times 460$.

hyaluronidase (fig 7), and an absence of staining after testicular hyaluronidase (fig 8). After the various incubations and staining with Alcian Blue at $\mathrm{pH} 5 \cdot 8$ with $0.05 \mathrm{M} \mathrm{MgCl} 2$ there were no unequivocal decreases in staining.

Similar results were achieved when sections of the myxoma associated with the gingiva and of the two umbilical cords were subjected to the incubations and staining with Alcian Blue at pH 2.5. However, the myxomatous material associated with the unerupted canine showed weak staining with Alcian Blue at pH $2 \cdot 5$, a slight increase after incubating in saline, a slight decrease after staphylococcal hyaluronidase when compared with the saline-treated sections, the intensity being similar to that of untreated sections, and a complete loss of staining after testicular hyaluronidase. In the 


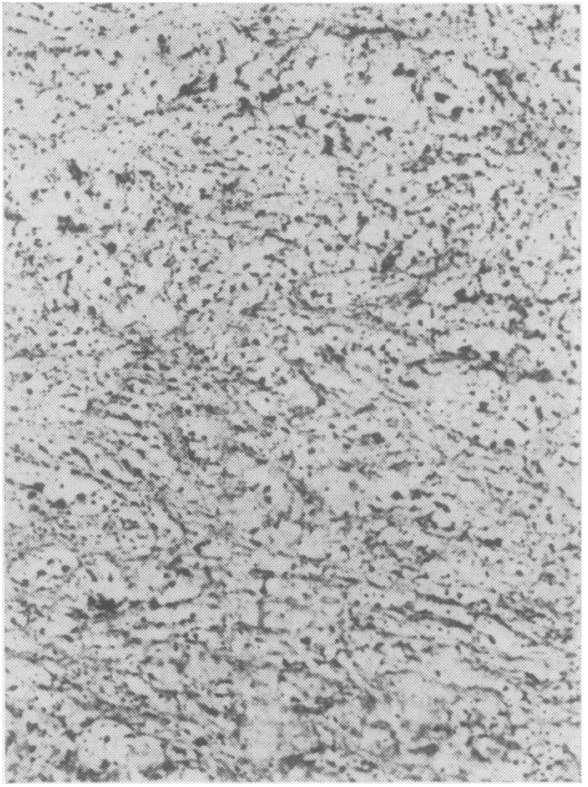

Fig 5

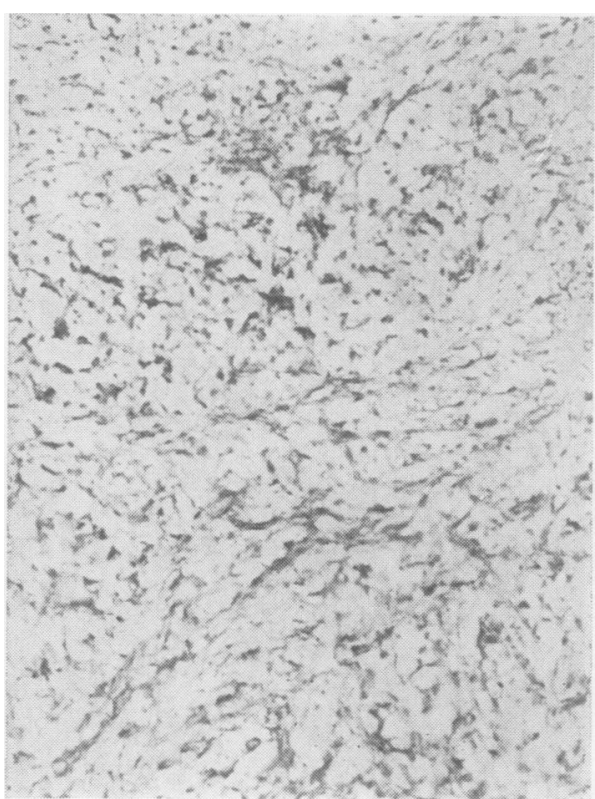

Fig 6

Fig 5 Untreated section stained with Alcian Blue at pH 2.5. Moderate staining is seen throughout. $\times 160$.

Fig 6 Adjacent section to fig 5, incubated in saline alone before staining with Alcian Blue at pH 2.5. There is some reduction in staining when compared with figure $5 . \times 160$.

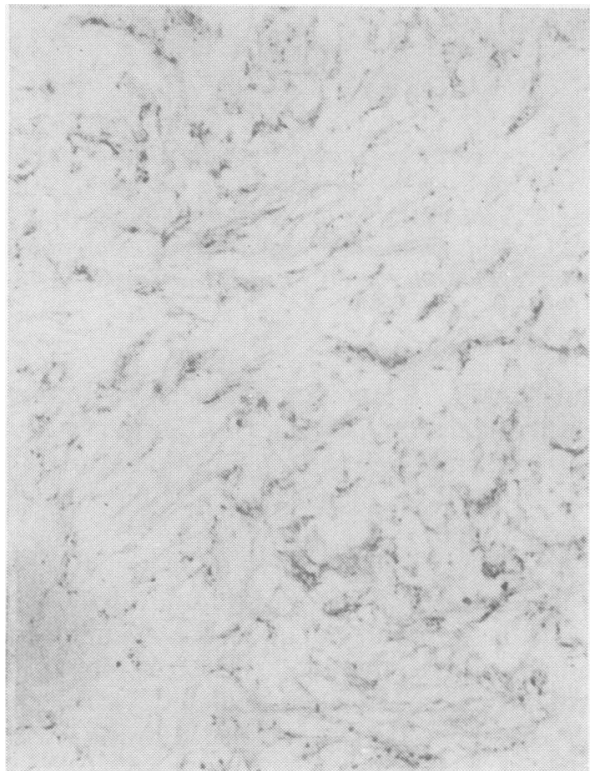

Fig 7

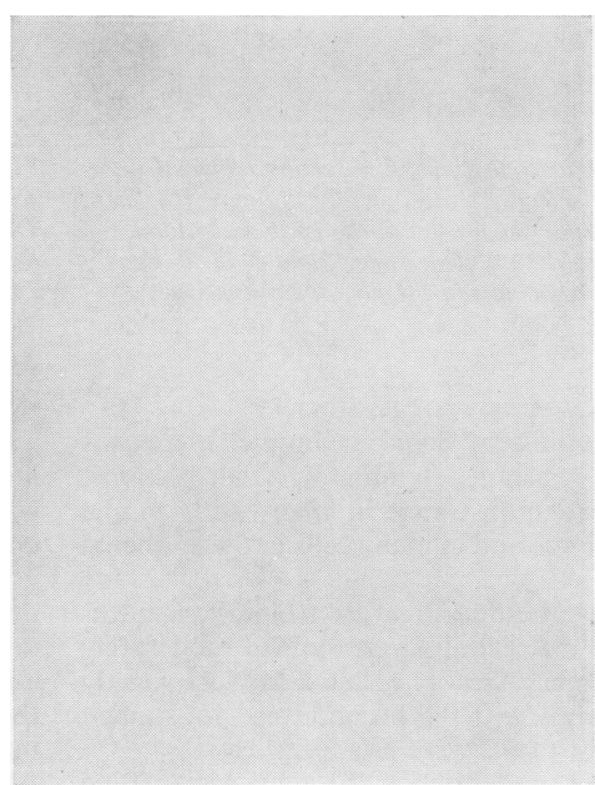

Fig 8

Fig 7 Adjacent section to fig 6, incubated with staphylococcal hyaluronidase before staining with Alcian Blue at pH 2.5. There is a considerable reduction in staining when compared with figure 6. $\times 160$.

Fig 8 Adjacent to fig 7, incubated with testicular hyaluronidase before staining with Alcian Blue at pH 2.5. There is no staining. $\times 160$. 
odontogenic fibroma only the faintest trace of stain was seen with Alcian Blue at $\mathrm{pH} 2.5$, and the intensity of staining was unaffected by saline or staphylococcal hyaluronidase, whilst no stain was seen after testicular hyaluronidase. The staining of the mucin in the buccal salivary glands was not affected by the various incubations.

\section{ENZYME HISTOCHEMISTRY}

The distribution of reaction products from the techniques for adenosine triphosphatase, nucleoside diphosphatase, and thiamine pyrophosphatase was similar. Reaction product was seen in many cells in the myxomatous tissue and was usually faint or weak, although some moderately stained cells were seen, and such cells were concentrated around epithelial islands with intercellular separation, a clear zone usually separating these cells from the island (fig 9). Faint staining of the cells in the islands was often seen.

Faint alkaline-phosphatase activity was infrequently seen outlining cells in the myxomatous tissue and rarely outlining cells in epithelial islands. Activity was not seen in the cells surrounding islands.

Intense acid-phosphatase, beta-glucuronidase, and non-specific esterase activities were seen in some cells in the myxomatous tissue, and these were frequently arranged around vessels (fig 10). Strong activities were demonstrated in foamy macrophages, and these were found in 'cavities' (fig 11). Activity was not seen in cells surrounding epithelial islands. In the cells of the epithelial islands, faint acidphosphatase activity was sometimes seen, faint non-specific esterase activity was rarely seen, and beta-glucuronidase activity was not seen. The nonspecific esterase activity appeared to be completely E600-resistant, except in the foamy macrophages, where it was entirely, or almost entirely, E600sensitive.

Moderate arylamidase activity was seen in cells which appeared to correspond to those with intense acid-phosphatase, beta-glucuronidase, and nonspecific esterase activities. Activity was seen in other cells in the myxomatous tissue and was usually faint, such cells often being seen around epithelial islands with intercellular separation in a similar distribution to the cells with moderate adenosine-triphosphatase, nucleoside-diphosphatase, and thiamine-pyrophosphatase staining. Faint activity was occasionally seen in cells in the islands.

Peroxidase, cytochrome-oxidase, succinicdehydrogenase, and NADH- and NADPH-diaphorase activities were not demonstrable. Control sections of a human submandibular gland were

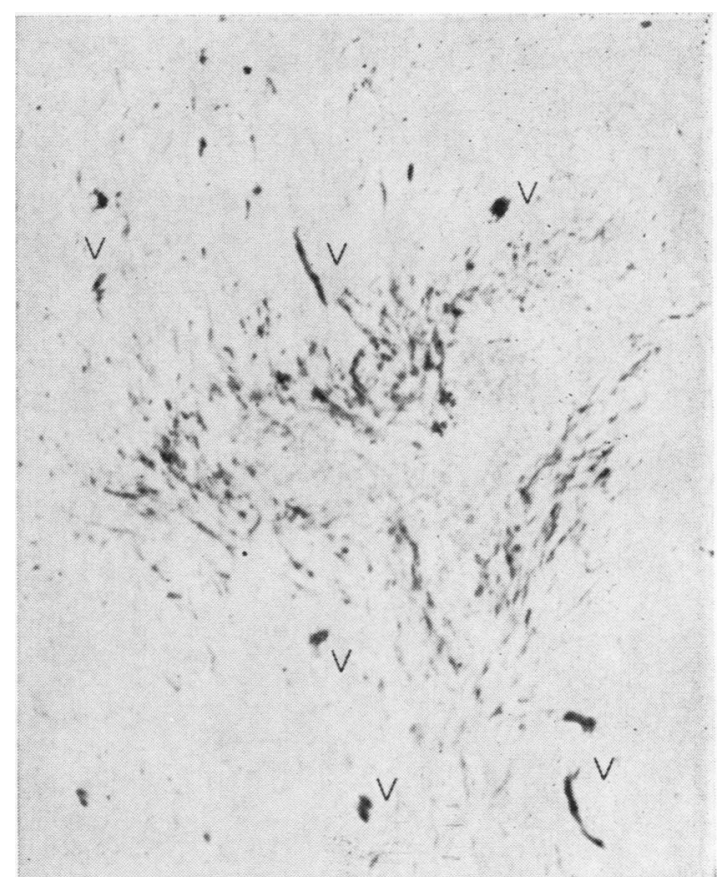

Fig 9 Section incubated in the inosine-diphosphatase medium for one hour at room temperature. The nuclei are counterstained with methyl green. Moderately stained cells are concentrated around an epithelial island, and are separated from it by a peri-insular clear zone.

Several moderately stained vessels (V) are present. $\times 70$.

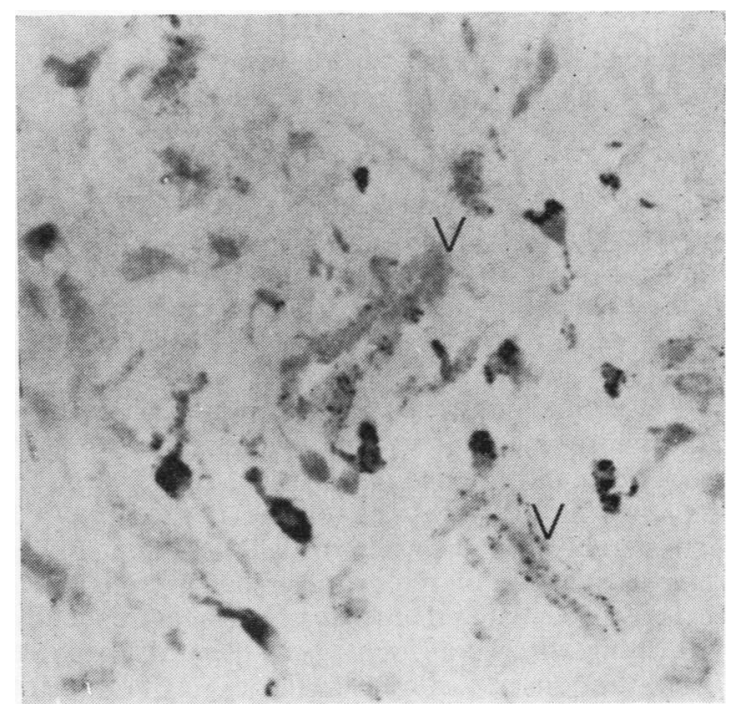

Fig 10 Section incubated in the non-specific esterase medium with eserine for 10 min at room temperature. Cells with intense activity and sections of a thin-walled vessel (V) with some granules of reaction product in the walls are seen. $\times 300$. 


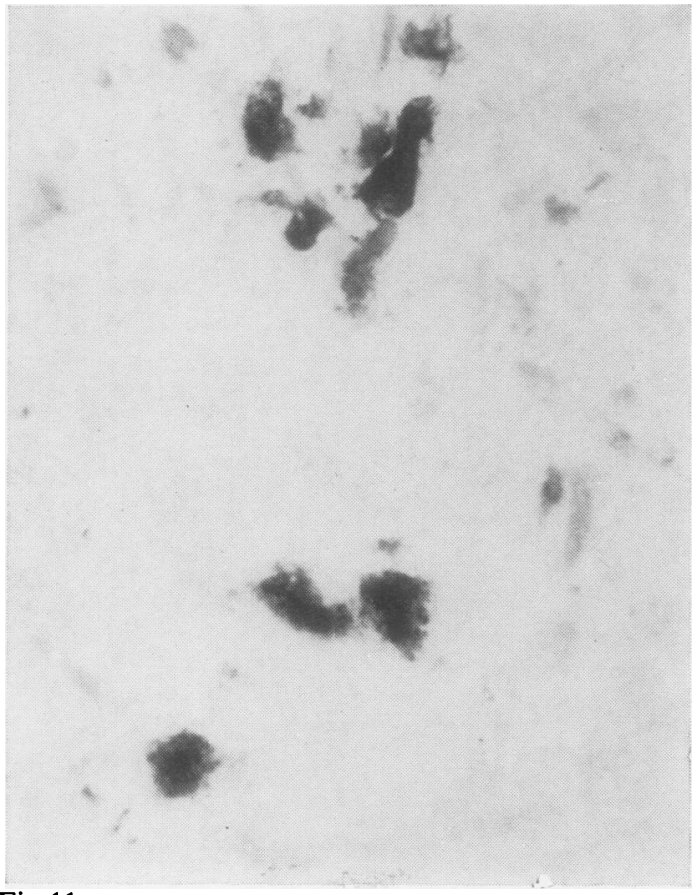

Fig 11

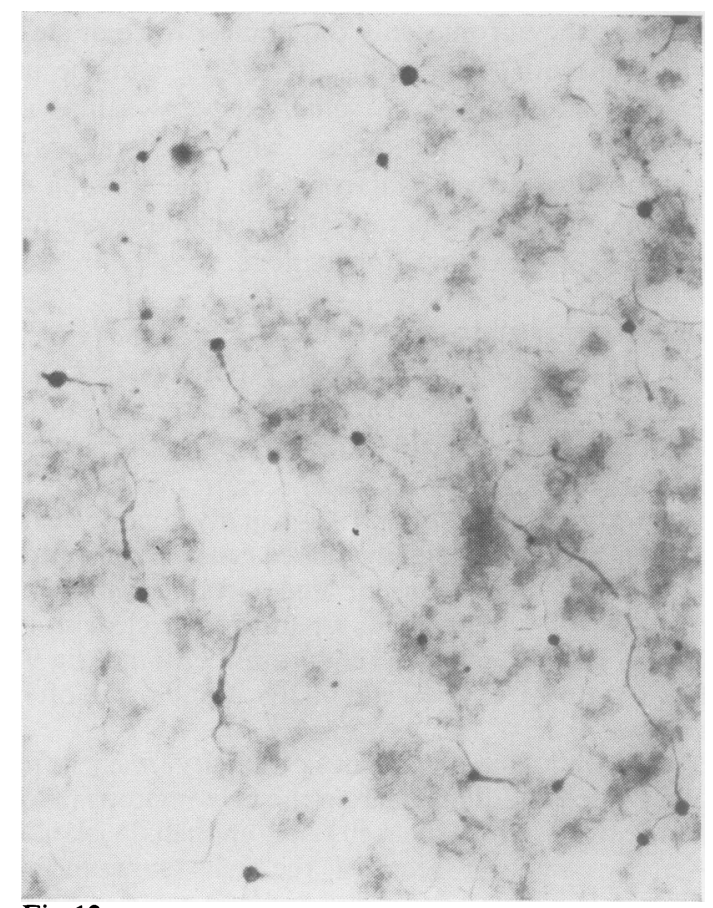

Fig 12

Fig 11 Section incubated in the non-specific esterase medium with eserine for 10 min at room temperature. Foamy macrophages with strong activity are associated with a cavity. $\times 400$.

Fig 12 Electron micrograph showing the ground substance which consists of amorphous material of low electron density and particles of high electron density with fibrillar processes. Lead citrate, $\times 22500$.

incubated in the media for the respiratory enzymes and strong activity was found in the ducts.

\section{ELECTRON MICROSCOPY}

Sections were cut through seven pieces of tissue and were examined by light microscopy in order to find epithelial islands and 'cavities'. On the basis of these findings, sections at several different levels in four pieces were cut for electron-microscopical examination.

The ground substance of the tumour consisted of amorphous material of low electron density and variable numbers of particles of high electron density (fig 12). The size of the particles varied considerably, but they were usually less than $700 \AA$ diameter. Many of the particles had fibrillar projections of a smaller diameter, which were frequently branching. In some regions where there were concentrations of particles, the fibrils were prominent and formed a network communicating with other fibrils and particles.

Variable amounts of banded collagen fibrils with a periodicity of about $660 \AA$ were present. Zones of ground substance were seen with no collagen fibrils whilst in other regions bundles of collagen fibrils were predominant.

On examination of the cells of the tumour a wide spectrum of appearance was found, and classification of cells was often difficult or impossible.

Many of the cells in the myxomatous tissue could be considered as secretory cells on account of prominent rough endoplasmic reticulum. In some the cisternae were narrow, whilst in others they were dilated and contained amorphous material (figs 13 and 14). A well developed Golgi apparatus was often seen (figs 13 and 14). These cells varied considerably in shape and size, cells whose longest dimension was above $20 \mu$ being seen (fig 13).

Several 'cavities' were found in one piece of tissue. They contained a considerable amount of amorphous material which was continuous with that in the surrounding ground substance, but electron-dense particles were seldom seen. The 'cavities' were surrounded by collagen fibrils which were intermixed with the contents at the periphery (figs 13 and 14). Cells which were considered as secretory cells (figs 13 and 14), cell debris, and macrophages filled 

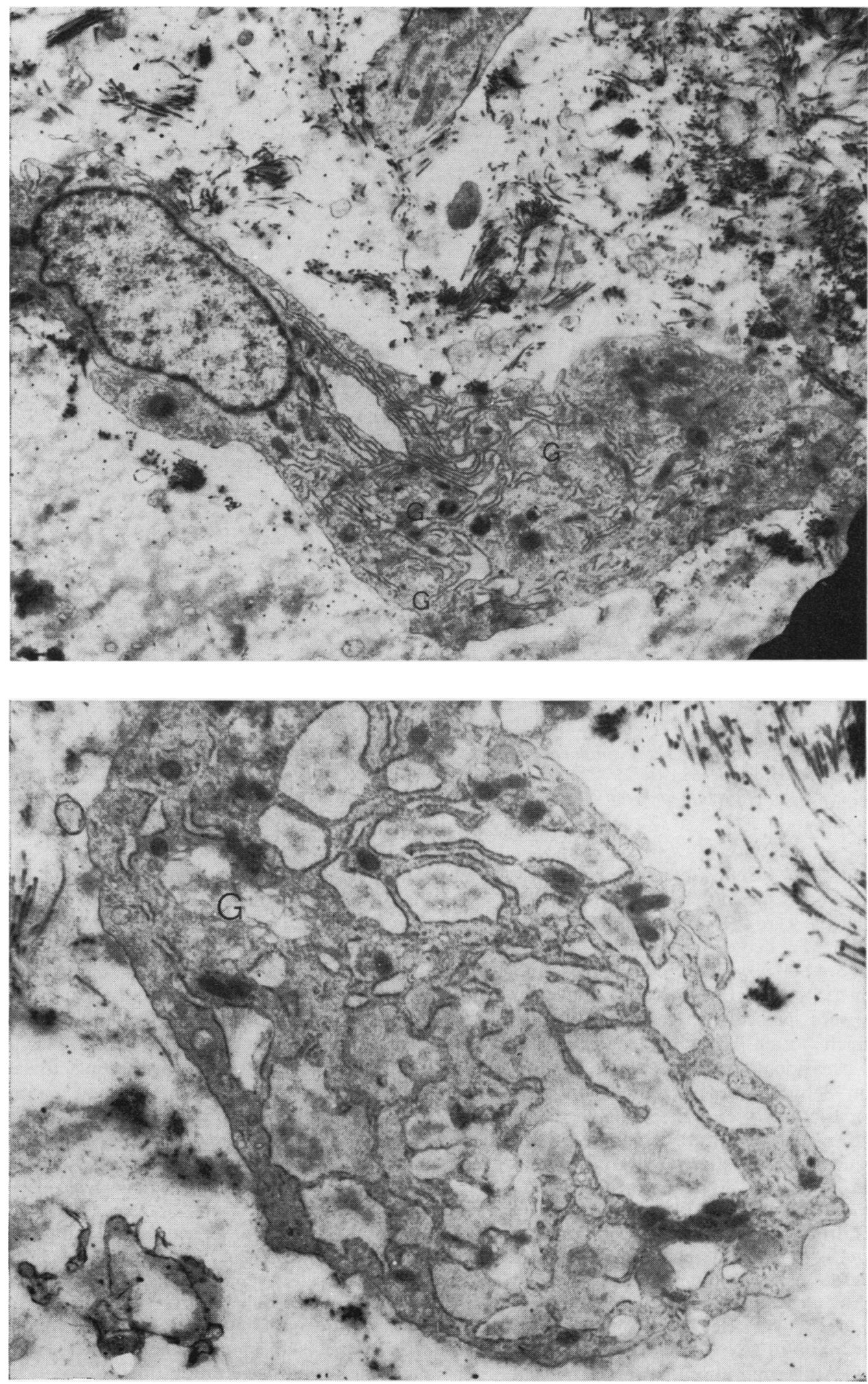

Fig 13 Electron

micrograph showing

a large cell

containing prominent rough endoplasmic

reticulum with some

dilated cisternae.

Several Golgi

apparatuses $(\mathrm{G})$ are

present. The cell is

situated at the

periphery of a

cavity which

contains a

considerable amount

of amorphous

material. Collagen

fibrils are seen

surrounding the

cavity at the top

right, and some are

seen in the cavity.

Uranyl acetate and lead citrate,

$\times 6000$.

Fig 14 Electron

micrograph showing

a cell with

prominent rough

endoplasmic

reticulum with

dilated cisternae

containing

amorphous material.

A prominent Golgi

apparatus is seen

(G). The cell is at

the periphery of $a$

cavity, and

amorphous material,

collagen fibrils, and

a little membranous

debris are seen.

Uranyl acetate and

lead citrate,

$\times 12500$. 


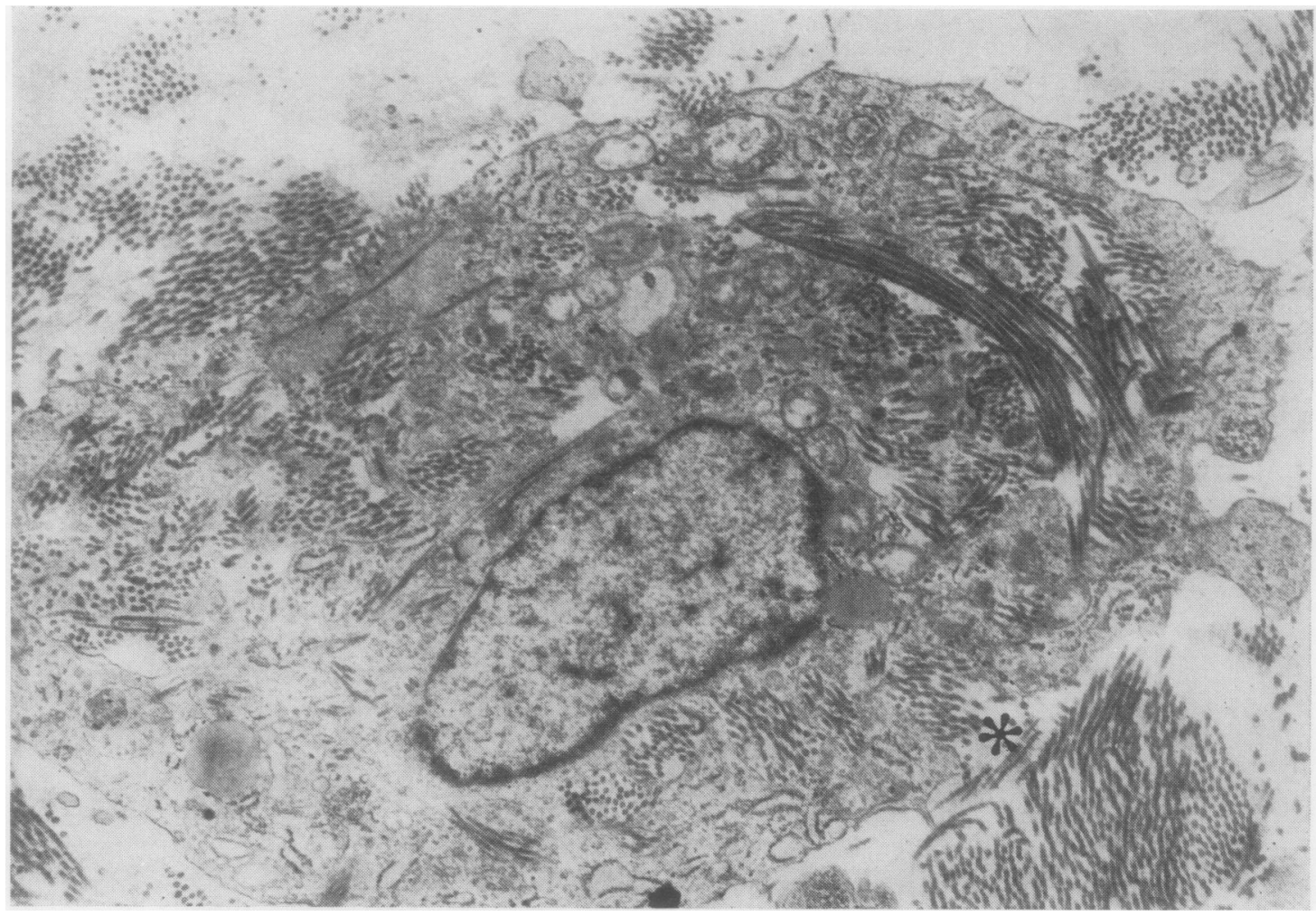

Fig 15 Electron micrograph showing a cell containing banded collagen fibrils in membrane-bound structures, one of which is seen to communicate with the exterior $\left(^{*}\right)$. A little rough endoplasmic reticulum and a Golgi apparatus near the periphery are seen. Uranyl acetate and lead citrate, $\times 13500$.

with membrane-bound granules of varying density, which appeared to correspond to light-microscopical foamy macrophages, were seen in the 'cavities'.

Cells containing banded collagen fibrils with a periodicity of about $660 \AA$ were seen in the myxomatous tissue (fig 15). The fibrils were usually in bundles, and were present in membrane-bound structures, which often contained amorphous material and occasionally electron-dense debris. Communication between these structures and the exterior was occasionally seen. These cells possessed a variable, but usually small, amount of rough endoplasmic reticulum, sometimes with moderately dilated cisternae containing amorphous material.

Three large epithelial islands were examined (figs 16 and 17). In one of these (fig 16) and in parts of the other two (fig 17), the intercellular spaces were small or moderately sized and usually appeared empty apart from a little amorphous material and membranous debris. Particles were not seen in these spaces. In parts of two of the islands (fig 17) there was considerable separation between epithelial cells with ground substance extending throughout large intercellular spaces. In some places there was loss of continuity of the peripheral layer of epithelial cells, and the basement membrane was seen separating large intercellular spaces from the periinsular region, although occasionally the basement membrane was incomplete with communication between large intercellular spaces and the peri-insular region. Invaginations of the surrounding tissues lined by basement membrane were seen in regions with little intercellular separation (figs 16 and 17). The epithelial cells contained little endoplasmic reticulum, usually with dilated empty cisternae and few attached ribosomes. Golgi apparatuses were 0 seldom seen and were small. Many of the cells $\stackrel{\mathscr{D}}{\stackrel{D}{2}}$ contained tonofilaments. Variable quantities of $\stackrel{\odot}{+}$ glycogen granules were seen. In the regions with little $T$ or moderate intercellular separation desmosomes and microvilli were seen. A clear zone relatively poor in fibres and cells and containing ground substance was seen around the islands, particularly where there was much intercellular separation (figs 16 and 17). 


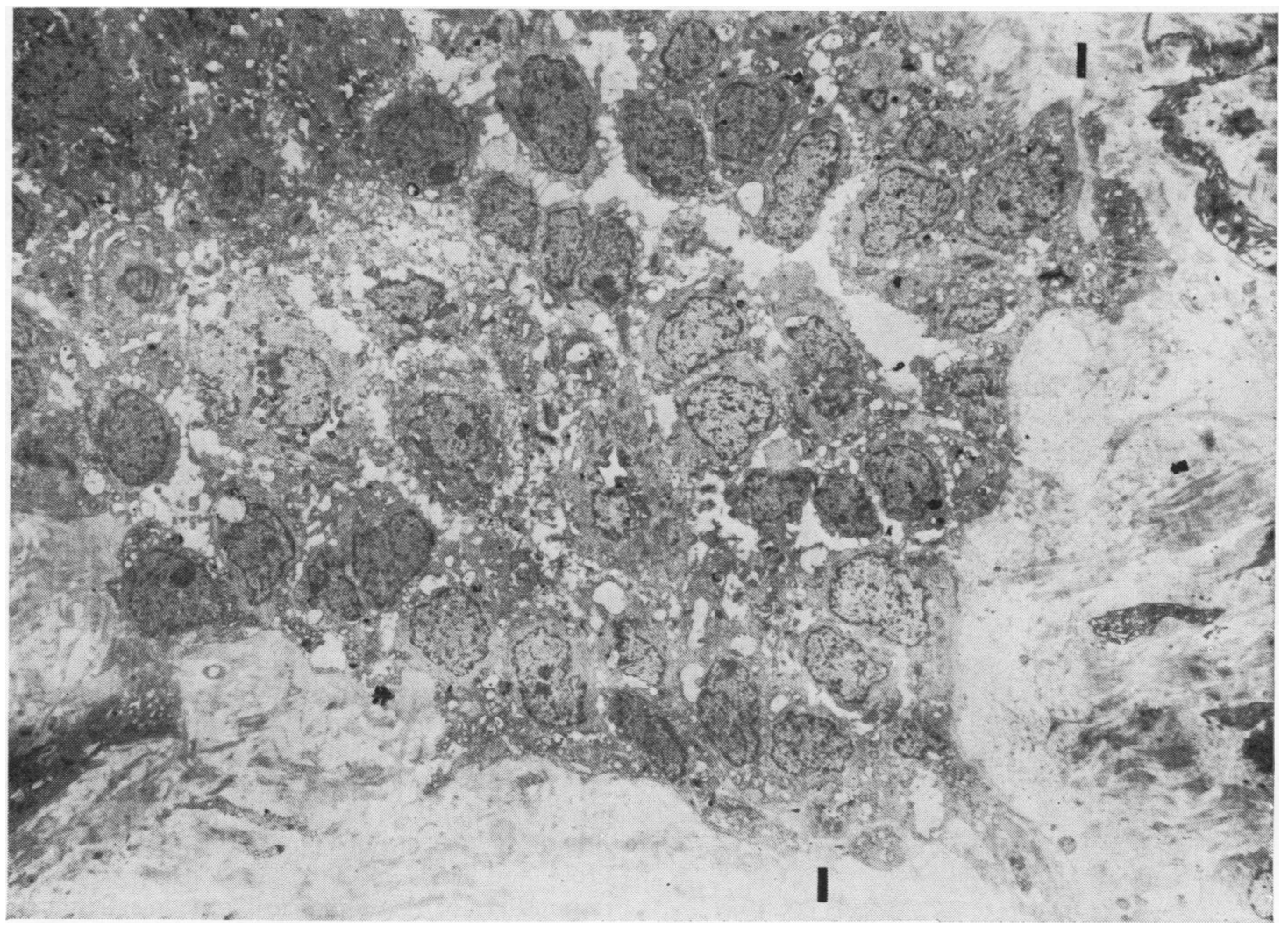

Fig 16 Electron micrograph of adjacent section to figure 3. An epithelial island is seen with small, and some moderately sized, intercellular spaces which are largely empty. A basement membrane surrounds the island and lines invaginations (I). A clear zone relatively poor in collagen fibrils and cells and containing ground substance is seen around the island. Lead citrate, $\times 1800$.

\section{Discussion}

Hodson and Prout (1968) found that of the total mucopolysaccharide present in a myxoma of the mandible $80 \%$ was hyaluronic acid and $20 \%$ chondroitin sulphate, and they suggested that a high hyaluronic acid content may be a characteristic feature of myxomas. In the three myxomas of the present investigation, the reduction in staining with Alcian Blue at pH 2.5 after staphylococcal hyaluronidase when compared with saline-treated sections and the abolition of staining after testicular hyaluronidase indicate the presence of hyaluronic acid and chondroitin sulphate A and/or C (Linker et al, 1956, 1960; Spicer et al, 1967), whilst in the odontogenic fibroma little chondroitin sulphate $A$ and/or $C$ and no hyaluronic acid were demonstrated.

In two of the myxomas in the present investigation, in the umbilical cords, and in the myxoma studied by Hodson and Prout (1968) incubation in saline alone appeared to cause a loss of acidic mucosubstance from the sections. One feature common to all these tissues appears to be the presence of hyaluronic acid, and possibly some of this is lost during the saline incubation. Although the presence of chondroitin sulphate $A$ and/or $C$ appears to be another feature common to these tissues, the odontogenic fibroma which contained no demonstrable hyaluronic acid but some chondroitin sulphate $\mathrm{A}$ and/or $\mathrm{C}$ did not show any decrease in staining after incubation in saline, suggesting that chondroitin sulphate $\mathbf{A}$ and/or $\mathrm{C}$ is not removed by saline. Hyaluronic acid appeared to be present in the myxoma associated with the unerupted canine, although there was an increase in staining after incubation in saline. Possibly this increase is due to reactive sites on acidic mucosubstances being exposed by the saline incubation. A similar unexplained increase in stain- 


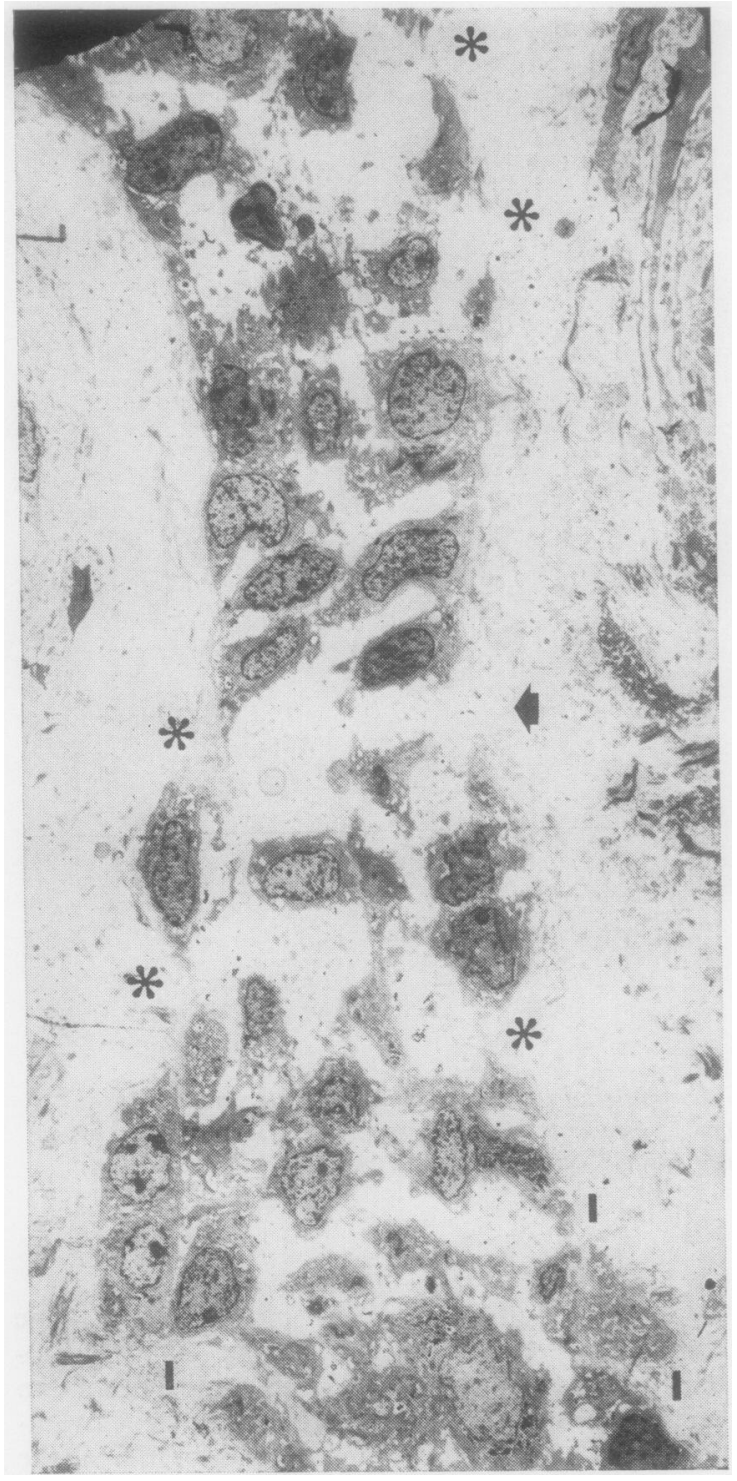

Fig 17 Electron micrograph of adjacent section to figure 4. An epithelial island is seen. In the lowest part of the micrograph there are some small intercellular spaces which are largely empty. Invaginations (I) lined by basement membrane are seen in this region. Elsewhere in the island there is considerable intercellular separation with ground substance being seen between the epithelial cells. The basement membrane appears to span intercellular spaces where there has been loss of continuity of the surface layer of cells (*). In one place it appears to be missing $(\leftarrow)$, there being an apparent continuity between intercellular space and the peri-insular region. Much of the island is surrounded by a clear zone containing ground substance. Uranyl acetate and lead citrate, $\times 1260$. ing was seen by Spicer et al (1967) in mouse and rat cornea after incubation in $0.1 \mathrm{M}$ phosphate buffer pH 5.5.

Although a decrease in staining intensity with Alcian Blue at $\mathrm{pH} 2.5$ was seen after the enzyme $\frac{\bar{\sigma}}{\bar{D}}$ incubations, it was not seen with Alcian Blue at $\bar{\phi}$ pH 5.8 with $0.05 \mathrm{M} \mathrm{MgCl}_{2}$. This retention of staining $\varrho$ is probably due to proteins which are weakly क negative at pH 5.8 (Scott and Dorling, 1965) still $\vec{\circ}$ being stained in the medium containing $0.05 \mathrm{M}-$ $\mathrm{MgCl}_{2}$. and masking the loss of mucosubstance. $\vec{\sigma}$ This suggests that the reduction in staining with the critical electrolyte concentration technique between $0.05 \mathrm{M}$ and $0.2 \mathrm{M}$ may not be entirely due to $\overparen{\circ}$ hyaluronic acid, which has a critical electrolyte ${ }_{0}^{\circ}$ concentration in the region of $0.1 \mathrm{M} \mathrm{MgCl}_{2}(\mathrm{Scott}-\mathrm{O}$ and Dorling, 1965). However, the staining at $0.4 \mathrm{M}_{\circ}$

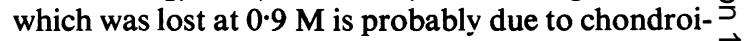
tin sulphate which has a critical electrolyte con- $\vec{\nabla}$ centration in the region of $0.5 \mathrm{M} \mathrm{MgCl}_{2}$ (Scott and Dorling, 1965).

The particles of high electron density seen in the $\stackrel{+}{+}$ ground substance at the ultrastructural level are $\vec{\theta}$ somewhat similar in appearance to particles which. $\omega$ appeared to contain acidic mucosubstance which was probably chondroitin sulphate found in cartilage matrix by Matukas, Panner, and Orbison (1967).

Hodson and Prout (Hodson and Prout, 1968;

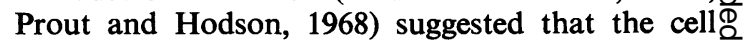
responsible for the myxoma is a neoplastic mesen- $\overrightarrow{\vec{F}}$ chymal cell which is secreting hyaluronic acid in $\frac{3}{3}$ excessive amount, and suggested that the term? 'myxoblast' would be suitable to distinguish it, metabolically if not morphologically, from the collagen-producing fibroblast. The ultrastructuralo findings support the view of Hodson and Prout that an active secretory cell is responsible for the myxoma, for many cells with the characteristics of secretoryo cells were found. The finding of secretory cells in 'cavities' suggests that an accumulation of secretory응 material from such cells produces these 'cavities'.

The absence of demonstrable respiratory enzyme activity in the tumour indicates a low level of respiratory activity, and is compatible with the slow growth of the tumour, which had been present at least three years.

The intense acid-phosphatase, beta-glucuronidase and E600-resistant esterase activities found in someo cells are probably lysosomal enzyme activities.\$ Possibly these cells are active macrophages, and the $e^{+}$ lower intensity of these enzyme activities in foamy macrophages possibly reflects a functional aging as macrophages become filled with engulfed material $\stackrel{\Omega}{\varrho}$ A similar observation has been made in other, pathological situations in man (J. D. Harrison, ino preparation) and in cat (Harrison, 1972). The 
apparent absence of E600-sensitive esterase activity in the cells with intense E600-resistant esterase activity may be due to this intense activity masking the E600-sensitive activity. In the 'cavities' the finding of cell debris as well as foamy macrophages packed with membrane-bound granules, which probably represent phagocytosed material, possibly suggests that macrophages may be engaged in removing cell debris from 'cavities'. However, macrophages appear to engulf the mucosubstance carrageenin (Pérez-Tamayo, 1970), and Matthiessen (1966) considered that the finding of macrophages, referred to as histiocytes, in the stellate reticulum of human tooth germs presumably related to these cells' attraction by the acidic mucosubstances present in this tissue. Furthermore, macrophages are associated with accumulations of mucosubstance which have arisen by extravasation from salivary glands in man (J. D. Harrison, in preparation) and cat (Harrison and Garrett, 1972; Harrison, 1972). Possibly macrophages in the odontogenic myxoma were involved in removing mucosubstances, and not primarily in removing cell debris. Perhaps some of the debris in the 'cavities' represents degenerated foamy macrophages, for Monis, Weinberg, and Spector (1968) found signs of degeneration in foamy macrophages in carrageenin granulomas.

Cells containing collagen fibrils have been found in human mesodermal tumours and inflammatory states (Welsh and Meyer, 1967) and in several situations where collagen breakdown is occurring (Pérez-Tamayo, 1970; Parakkal, 1972; Ten Cate, 1972). These cells, which were considered as fibroblasts (Pérez-Tamayo, 1970; Ten Cate, 1972) and macrophages (Parakkal, 1972), appear to be phagocytosing collagen, and possibly the cells containing collagen fibrils found in the odontogenic myxoma are also involved in collagen breakdown by phagocytosis. Perhaps this may be a factor in the formation of the 'cavities'.

The frequent association of cells containing intense acid-phosphatase, beta-glucuronidase, and E600-resistant esterase activities with vessels is similar to the finding by Matthiessen (1966) of cells with high levels of acid-phosphatase and nonspecific esterase activities in a perivascular distribution in the mesenchyme of human tooth germs. This could be a manifestation of the haematological origin of macrophages, and in the odontogenic myxoma some of these cells may possibly be involved in collagen removal, for vessels were frequently associated with 'cavities'.

The epithelial islands do not appear to be present as fortuitous inclusions of inactive epithelium, and a morphological variation is seen from islands similar to the epithelial rests of Malassez (Valderhaug and
Nylen, 1966) to islands with widely separated cells similar to the stellate reticulum of the enamel organ (Fischlschweiger, Provenza, and Sisca, 1967; Sisca, Provenza, and Fischlschweiger, 1967). These similarities strongly suggest that the islands consist of odontogenic epithelium.

Although the basement membrane usually maintained the outline of the islands where there was loss of continuity of the peripheral cells, it appeared to be missing in some places and continuity between intercellular spaces and the surrounding region was seen. This contrasts with the situation in the human enamel organ where the continuity of the basement membrane is maintained when there is loss of cellular continuity in the outer enamel epithelium in the intermediate bell stage. The basement membrane in such areas is relocated into and through the outer enamel epithelium and extends between stellatereticulum cells, the invaginations containing dental sac material (Fischlschweiger et al, 1967). The appearance of these invaginations is similar to that of invaginations in regions with little separation between cells in the islands examined ultrastructurally.

Possibly there is a development of epithelial rests to produce a stellate-reticulum arrangement with an eventual loss of continuity between epithelial cells. There may sometimes be a relocation of the basement membrane, whilst at other times there is no relocation and the basement membrane breaks down, allowing an ingress of ground substance which surrounds widely separated epithelial cells.

The epithelial islands with separation between cells appear to produce a reaction in the surrounding tissue. This was manifested by the clear zone surrounding such islands and the increased prominence of reaction product from the techniques for adenosine triphosphatase, nucleoside diphosphatase, and thiamine pyrophosphatase, and often arylamidase, in cells around these islands. Although islands with a stellate-reticulum-like arrangement and peri-insular clear zones do not appear to have been previously found in odontogenic myxomas, they are found in ameloblastic fibroma (Pindborg, 1970). Pindborg (1970) suggested that the presence of immature mesodermal tissue in this tumour may be explained as the result of an inductive effect on the part of odontogenic epithelium. The same suggestion may be applied to the odontogenic myxoma in the present investigation, and the myxomatous appearance may be the result of an aberrant development of mesodermal cells into 'myxoblasts'. The finding of similar features in the present odontogenic myxoma and the ameloblastic fibroma supports the concept (Pindborg, 1970) that, rather than distinct and separate types, there is a continuous spectrum of odontogenic tumours. 
I gratefully acknowledge the financial support of the Wellcome Trust; the technical assistance of $\mathrm{Mr}$ P.S. A. Rowley with the preparation of the material for electron-microscopical examination and with the photographs, of Mr K. J. Davies with the photographs, and of Miss M. R. Atkins with the histological procedures; and the gift of staphylococcal hyaluronidase from Organon Laboratories Ltd. I am grateful to Mr M. Harris for the specimen.

\section{References}

Barka, T., and Anderson, P. J. (1962). Histochemical methods for acid phosphatase using hexazonium pararosanilin as coupler. J. Histochem. Cytochem., 10, 741-753.

Barros, R. E., Dominguez, F. V., and Cabrini, R. L. (1969). Myxoma of the jaws. Oral Surg., 27, 225-236.

Bulmer, D., and Fisher, A. W. F. (1970). Studies on the characterization and localization of rat placental esterases. J. Histochem. Cytochem., 18, 722-729.

Burstone, M. S. (1961). Modifications of histochemical techniques for the demonstration of cytochrome oxidase. J. Histochem. Cytochem., 9, 59-65.

Cawson, R. A. (1972). Myxoma of the mandible with a 35 year followup. Brit. J. oral Surg., 10, 59-63.

Davis, B. J. (1959). Histochemical demonstration of erythrocyte esterases. Proc. Soc. exp. Biol. (N.Y.), 101, 90-93.

Fischlschweiger, W., Provenza, D. V., and Sisca, R. F. (1967). Reorganization of the peripheral layers of the human ename organ during the bell stage-an electron microscopic study. J. Balt. Coll. Dent. Surg., 22, 28-55.

Fullmer, H. M. (1965). The histochemistry of the connective tissues. Int. Rev. connective Tissue Res., 3, 1-76.

Gorlin, R. J. (1970). Odontogenic tumors. In Thoma's Oral Pathology, edited by R. J. Gorlin and H. M. Goldman, 6th ed., pp. 481-515. Mosby, St. Louis.

Graham, R. C., Jr., and Karnovsky, M. J. (1966). The early stages of absorption of injected horseradish peroxidase in the proximal tubules of mouse kidney: ultrastructural cytochemistry by a new technique. J. Histochem. Cytochem., 14, 291-302.

Harrison, J. D. (1972). The effects of duct ligation of salivary glands of cat studied by histological and histochemical methods. PhD Thesis, University of London.

Harrison, J. D., and Eggleston, D. J. (1973). Odontogenic myxoma of the maxilla; case report and some interesting histological findings. Brit. J. oral Surg., 11, 28-32.

Harrison, J. D., and Garrett, J. R. (1972). Mucocele formation in cats by glandular duct ligation. Arch. oral Biol., 17, 1403-1414.

Hayashi, M., Nakajima, Y., and Fishman, W. H. (1964). The cytologic demonstration of $\beta$-glucuronidase employing naphthol AS-BI glucuronide and hexazonium pararosanilin; a preliminary report. J. Histochem. Cytochem., 12, 293-297.

Hodson, J. J., and Prout, R. E. S. (1968). Chemical and histochemical characterization of mucopolysaccharides in a jaw myxoma. J. clin. Path., 21, 582-589.

Karnovsky, M. J. (1965). A formaldehyde-glutaraldehyde fixative of high osmolarity for use in electron microscopy. J. Cell Biol., 27, 137A-138A.

Koelle, G. B. (1955). The histochemical identification of acetylcholinesterase in cholinergic, adrenergic and sensory neurons. J. Pharm. exp. Ther., 114, 167-184.

Linker, A., Hoffman, P., Meyer, K. Sampson, P., and Korn, E. D. (1960). The formation of unsaturated disacharides from mucopolysaccharides and their cleavage to $\alpha$-keto acid by bacterial enzymes. J. biol. Chem., 235, 3061-3065.

Linker, A., Meyer, K., and Hoffman, P. (1956). The production of unsaturated uronides by bacterial hyaluronidases. J. biol. Chem., 219, 13-25.

Matthiessen, M. E. (1966). Enzyme histochemistry of the prenatal development of human deciduous teeth. I. Alkaline phosphatase, acid phosphatase and unspecific AS-esterase. Acta anat. (Basel), 63, 523-544.

Matukas, V. J., Panner, B. J., and Orbison, J. L. (1967). Studies on ultrastructural identification and distribution of proteinpolysaccharide in cartilage matrix. J. Cell Biol., 32, 365-377.
Monis, B., Weinberg, T., and Spector, G. J. (1968). The carrageenan granuloma in the rat: a model for the study of the structure and function of macrophages. Brit. J. exp. Path., 49, 302-310.

Mowry, R. W. (1956). Alcian blue technics for the histochemical study of acidic carbohydrates. J. Histochem. Cytochem., 4, 407.

Nachlas, M. M., Monis, B., Rosenblatt, D., and Seligman, A. M (1960). Improvement in the histochemical localization of leucine aminopeptidase with a new substrate, L-leucyl-4methoxy-2-naphthylamide. J. biophys. biochem. Cytol., 7, 261 264.

Nachlas, M. M., Tsou, K. C., de Souza, E., Cheng, C. S., and Seligman, A. M. (1957). Cytochemical demonstration of succinic $\vec{\odot}$ dehydrogenase by the use of a new p-nitrophenyl substituted ditetrazole. J. Histochem. Cytochem., 5, 420-436.

Parakkal, P. F. (1972). Macrophages: the time course and sequence of $\vec{\omega}$ their distribution in the postpartum uterus. J. ultrastruct. Res. $\frac{\text { ती }}{40,284-291 \text {. }}$

Patterson, E. K., Hsiao, S. H., and Keppel, A. (1963). Studies on i dipeptidases and aminopeptidases. I. Distinction between $\sigma$ leucine aminopeptidase and enzymes that hydrolyze L-leucyl- $\infty$ $\beta$-naphthylamide. J. biol. Chem., 238, 3611-3620.

Pérez-Tamayo, R. (1970). Collagen resorption in carrageenin granulomas. II. Ultrastructure of collagen resorption. Lab. Invest., 22, 142-159.

Pindborg, J. J. (1970). Odontogeric tumors. In his. Pathology of the Dental Hard Tissues, pp. 367-428. Munksgaard, Copenhagen.

Prout, R. E. S., and Hodson, J. J. (1968). Analysis of the mucopolysaccharide of a myxoma of the mandible. Nature (Lond.), 218, 99-100.

Rodriguez, E. M. (1969). Fixation of the central nervous system by perfusion of the cerebral ventricles with a threefold aldehyde $\vec{C}$ mixture. Brain Res., 15, 395-412.

Scarpelli, D. G., Hess, R., and Pearse, A. G. E. (1958). The cyto- $\omega$ chemical localization of oxidative enzymes. 1. Diphosphopyridine nucleotide diaphorase and triphosphopyridine nucleotide diaphorase. J. biophys. Biochem. Cytol., 4, 747-752.

Scott, J. E., and Dorling, J. (1965). Differential staining of acid glycosaminoglycans (mucopolysaccharides) by alcian blue in $\bar{O}$ salt solutions. Histochemie, 5, 221-233.

Sedano, H. O., and Gorlin, R. J. (1965). Odontogenic myxoma : some $\frac{2}{\mathbb{D}}$ histochemical considerations. Arch. oral Biol., 10, 727-729.

Sisca, R. F., Provenza, D. V., and Fischlschweiger, W. (1967). $\overrightarrow{\overrightarrow{0}}$ Ultrastructural characteristics of the human enamel organ in an early stage of development. J. Balt. Coll. Dent. Surg., 22, 8-27.

Smith, R. E., and Farquhar, M. G. (1970). Modulation in nucleoside diphosphatase activity of mammotrophic cells of the rat adenohypophysis during secretion. J. Histochem. Cytochem., 18, 응 237-250.

Spicer, S. S., Horn, R. G., and Leppi, T. J. (1967). Histochemistry of $\frac{\sigma}{3}$ connective tissue mucopolysaccharides. In The Connective. Tissue, edited by B. M. Wagner and D. E. Smith, pp. 251-303. Williams and Wilkins, Baltimore.

Stoward, P. J. (1967). The histochemical properties of some periodatereactive mucosubstances of the pregnant Syrian hamster음 before and after methylation with methanolic thionyl chloride. J. roy. micr. Soc., 87, 77-103.

Stutte, H. J. (1967). Hexazotiertes Triamino-tritolyl-methanchlorid을. (Neufuchsin) als Kupplungssaiz in der Fermenthistochemie. Histochemie, 8, 327-331.

Ten Cate, A. R. (1972). Morphological studies of fibrocytes in connective tissue undergoing rapid remodelling. J. Anat. (Lond.), 112, 401-414.

Valderhaug, J. P., and Nylen, M. U. (1966). Function of epithelial $\omega$ rests as suggested by their ultrastructure. J. periodont. Res., $1 \frac{\sigma}{<}$ 69-78.

Wachstein, M., and Meisel, E. (1957). Histochemistry of hepatice phosphatases at a physiologic pH. Amer. J. clin. Path., 27, 13-D 23.

Welsh, R. A., and Meyer, A. T. (1967). Intracellular collagen fibers $\square$ in human mesenchymal tumors and inflammatory states. $A r c h$. Path., 84, 354-362.

Whitman, R. A., Stewart, S., Stoopack, J. G., and Jerrold, T. L. (1971) Myxoma of the mandible: report of case. J. oral Surg., 29, 63 70 .

Zimmerman, D. C., and Dahlin, D. C. (1958). Myxomatous tumors o the jaws. Oral Surg., 11, 1069-1080. 